\title{
BATAS USIA PENSIUN GURU SWASTA DITINJAU BERDASARKAN UNDANG-UNDANG NOMOR 13 TAHUN 2003 TENTANG KETENAGAKERJAAN
}

\author{
Hafin Auni Qashrina \\ hafin.auni@yahoo.com \\ Universitas Airlangga
}

\begin{abstract}
In Law No. 13 of 2003 about Employment regulates labor regulations in general, but a strict and clear regulation concerning how many retirement age limits apply is not regulated. The absence of such regulation includes workers in the government and non-government field. In some government workers as well as Soldiers/Police, Judges there are clear retirement age rules in the relevant professional law, but this is different from the teaching profession becausew many teachers work not only in government employment status but also in non-status government. In Law No. 14 of 2005 concerning Teachers and Lectures, teachers who are appointed and placed are divided into2 (two), namely: a. Civil Servant Teacher; $b$. Private Teacher. The regulation also stipulates the teacher retirement age limit which is set at the age of 60 years. Nonetheless, a strict distinction between the retirement age limit for Publict Servants Teachers and Private Teachers is not regulated, this results in the practice of Private Education Providers applying the retirement age requirement for Private Teachers less than 60 years.
\end{abstract}

Keywords: Termination of Employment; Retirement Age; Private Teachers.

\begin{abstract}
Abstrak
Dalam Undang-Undang Nomor 13 Tahun 2003 tentang Ketenagakerjaan mengatur aturan-aturan ketenagakerjaan secara umum, tetapi pengaturan yang tegas dan jelas mengenai berapa batas usia pensiun yang berlaku tidak diatur. Tidak adanya pengaturan tersebut meliputi pekerja pada bidang pemerintahan maupun non pemerintahan. Pada beberapa pekerja dalam pemerintahan seperti halnya Tentara/|Polisi, Hakim, telah terdapat aturan batas usia pensiun yang jelas dalam undangundang profesi terkait, tetapi hal tersebut berbeda dengan profesi guru karena banyak guru yang bekerja tidak hanya dalam status pekerja pemerintahan namun juga dalam status non pemerintahan. Dalam Undang-Undang Nomor 14 Tahun 2005 tentang Guru dan Dosen, guru yang diangkat dan ditempatkan dibedakan menjadi 2 (dua), yaitu: a. Guru Pegawai Negeri; b. Guru Swasta. Dalam peraturan tersebut diatur pula batas usia pensiun guru yang diatur pada usia 60 tahun. Meskipun demikian pembedaan yang tegas antara batas usia pensiun Guru Pegawai Negeri dan Guru Swasta tidak tidak diatur, hal tersebut berakibat pada praktik Penyelenggara Pendidikan Swasta yang menerapkan ketentuan usia pensiun untuk Guru Swasta kurang dari 60 tahun.
\end{abstract}

Kata Kunci: Pemutusan Hubungan Kerja; Usia Pensiun; Guru Swasta.

\section{Pendahuluan}

Berakhirnya suatu hubungan kerja ini diatur pada Pasal 1603 e dalam KUHPerdata atau Burgelijke Wetboek (selanjutnya disebut BW) pada Buku III, Bab IVA tentang perjanjian untuk melakukan pekerjaan. Dalam pasal tersebut disebutkan bahwa hubungan kerja berakhir demi hukum jika habis waktu yang 
telah ditetapkan dalam perjanjian atau peraturan perusahaan atau dalam peraturan perundang-undangan. Putusnya hubungan kerja antara pengusaha dan pekerja berarti mengakibatkan hubungan hukum antara pengusaha dengan pekerja berakhir demikian juga hak dan kewajiban para pihak. Hal tersebut sebagaimana dirumuskan dalam ketentuan Pasal 1 angka 25 Undang-Undang Nomor 13 Tahun 2003 tentang Ketenagakerjaan sebagai berikut: "Pemutusan hubungan kerja adalah pengakhiran hubungan kerja karena suatu hal tertentu yang mengakibatkan berakhirnya hak dan kewajiban antara pekerja/buruh dan pengusaha."

Dalam Undang-Undang Nomor 13 Tahun 2003 tentang Ketenagakerjaan mengatur aturan-aturan ketenagakerjaan secara umum, namun apabila dilihat dari pengertian Ketenagakerjaan pada Pasal 1 Undang-Undang Nomor 13 Tahun 2003 tentang Ketenagakerjaan yaitu: "Segala hal yang berhubungan dengan tenaga kerja pada waktu sebelum, selama, dan sesudah masa kerja"; maka pengaturan ketenagakerjaan dalam undang-undang tersebut belum menyentuh seluruh aspek khususnya perihal aturan mengenai tenaga kerja setelah mengakhiri masa kerja, misalnya, mengenai pengaturan batas usia pensiun yang berlaku, baik untuk lingkup pekerja bidang pemerintahan maupun non pemerintahan tidak dibahas dalam peraturan ini.

Ketentuan yang ada, secara khusus hanya mengatur batas usia pensiun bagi pekerja sektor pemerintahan seperti Pegawai Negeri Sipil antara lain batas usia pensiun pada jabatan tertentu seperti guru, dosen, dan pegawai negeri/pejabat negara: PNS, Hakim, Tentara/Polisi. ${ }^{1}$ Sedangkan batas usia pensiun untuk pekerja sektor swasta yang sering terjadi di masyarakat selama ini banyak merujuk pada ketetntuan yang mengatur hak-hak yang bekaitan dengan masa pensiun, seperti Undang-Undang Nomor 3 Tahun 1992 tentang Jaminan Sosial Tenaga Kerja dan Undang-Undang Nomor 11 Tahun 1992 tentang Dana Pensiun.

Dalam ketentuan Pasal 14 ayat (1) Undang-undang Nomor 3 Tahun 1992 tentang Jaminan Sosial Tenaga Kerja terdapat ketentuan bahwa Jaminan Hari

${ }^{1}$ Serikat Pekerja PT. Tanjungenim Lestari Pulp And Paper, 'Usia Pensiun Jadi Pertanyaan', $<$ http://sppt-tel.blogspot.co.id/2015/12/usia-pensiun-jadi-pertanyaan.html>, diunduh 25 Juli 2017. 
Tua (JHT) dibayarkan kepada tenaga yang telah mencapai usia 55 tahun. Namun kemudian Undang-undang tersebut dicabut dan dinyatakan tidak berlaku melalui ketentuan Pasal 69 Undang-Undang Nomor 24 Tahun 2011 tentang Badan Penyelenggara Jaminan Sosial.

Kemudian pada tahun 2015 muncul ketentuan terkait yang mengatur perihal pensiun meliputi usia pensiun yaitu Peraturan Pemerintah Nomor 45 Tahun 2015 tentang Penyelenggaraan Program Jaminan Pensiun. Pada Pasal 15 Peraturan Pemerintah tersebut terdapat ketentuan sebagai berikut :

(1) Untuk pertama kali Usia Pensiun ditetapkan 56 (lima puluh enam) tahun.

(2) Mulai 1 Januari 2019, Usia Pensiun sebagaimana dimaksud pada ayat (1) menjadi 57 (lima puluh tujuh) tahun.

(3) Usia Pensiun sebagaimana dimaksud pada ayat (2) selanjutnya bertambah 1 (satu) tahun untuk setiap 3 (tiga) tahun berikutnya sampai mencapai Usia Pensiun 65 (enam puluh lima) tahun.

(4) Dalam hal Peserta telah memasuki Usia Pensiun tetapi yang bersangkutan tetap dipekerjakan, Peserta dapat memilih untuk menerima Manfaat Pensiun pada saat mencapai Usia Pensiun atau pada saat berhenti bekerja dengan ketentuan paling lama 3 (tiga) tahun setelah Usia Pensiun.

Pada beberapa pekerja dalam pemerintahan seperti halnya Tentara/Polisi, Hakim, telah terdapat aturan batas usia pensiun yang jelas dalam undang-undang profesi terkait, tetapi hal tersebut berbeda dengan profesi guru karena. Meskipun ketentuan tentang Guru dan Dosen telah diberlakukan, banyak guru yang bekerja tidak hanya dalam status pekerja pemerintahan namun juga dalam status non pemerintahan.

Undang-Undang Nomor 14 Tahun 2005 tentang Guru dan Dosen mengatur secara khusus profresi guru. Dalam ketentuan Pasal 25 Undang-undang tersebut, memilah pengangkatan dan penempatan guru berdasarkan dua kelembagaan, yaitu:

a. Guru pada satuan pendidikan yang diselenggarakan Pemerintah atau pemerintah daerah diatur dengan Peraturan Pemerintah (untuk selanjutnya dalam penulisan ini, istilah guru pada satuan dimaksud akan disebut menjadi Guru Pegawai Negeri), dan

b. Guru pada satuan pendidikan yang diselenggarakan masyarakat dilakukan oleh penyelenggara pendidikan atau satuan pendidikan yang bersangkutan berdasarkan perjanjian kerja atau kesepakatan bersama (untuk selanjutnya 
dalam penulisan ini, istilah guru pada satuan dimaksud akan disebut menjadi Guru Swasta).

Lebih lanjut terkait pengaturan batas usia pensiun guru, dalam ketentuan Pasal 30 Undang-Undang Guru dan Dosen terdapat ketentuan mengenai batas usia pensiun guru yaitu pada usia 60 tahun.

Sebagaimana ketentuan Pasal 25 yang terdapat pemilahan mengenai kelembagaan yang melakukan pengangkatan dan penempatan guru, pada ketentuan Pasal 30 tersebut tidak diatur secara jelas apakah ketentuan usia pensiun tersebut berlaku langsung untuk Guru Pegawai Negeti, atau hanya berlaku untuk Guru Swasta.

Praktek yang seringkali terjadi pada satuan Penyelenggaran Pendidikan Swasta, batas usia pensiun guru ditentukan dan diatur menggunakan Perjanjian Kerja, Peraturan Perusahaan atau Perjanjian Kerja. Selain itu, batas usia pensiun yang yang digunakan juga kurang dari ketentuan usia 60 (enam puluh) tahun sebagaimana yang diatur Undang-Undang Nomor 14 Tahun 2005 tentang Guru dan Dosen.

\section{Pemutusan Hubungan Kerja Guru Karena Batas Usia Pensiun Kurang Dari Ketentuan Undang-Undang Guru dan Dosen Pada Satuan Pendidikan Swasta}

Dalam teori Hukum Ketenagakerjaan dan Undang-Undang Nomor 13 Tahun 2003 tentang Ketenagakerjaan dikenal adanya 4 (empat) jenis PHK atau pemutusan hubungan kerja yaitu:

1. PHK demi hukum;

a. Perjanjian kerja untuk waktu tertentu (Pasal 164 ayat (1), 167 ayat(5), 154 huruf $b$ );

b. Pekerja/buruh meninggal dunia (Pasal 166);

2. PHK oleh pihak pekerja;
a. Masa percobaan;
b. Pekerja mengundurkan diri (Pasal 162 ayat (2));
c. Pekerja/buruh dapat memutuskan hubungan kerja sewaktu-waktu;
d. Pekerja/buruh berdasarkan alasan mendesak dapat mengajukan permohonan PHK kepada lembaga penyelesaian perselisihan hubungan industrial (Pasal 169 ayat (2));
e. Pekerja/buruh yang sakit (Pasal 172). 
3. PHK oleh pihak pengusaha/pemberi kerja;

Merupakan PHK oleh pihak pengusaha yang timbul karena keinginan dari pihak pengusaha dengan alasan, persyaratan dan prosedur tertentu. PHK dalam hal ini sering terjadi, baik karena pihak pekerja melakukan kesalahan ataupun karena kondisi perusahaan, misalnya, pada ketetentuan Pasal 161, 163, 154 ayat (3), 168, 169 ayat (3), 61 ayat (4).

4. PHK oleh pengadilan.

Merupakan PHK oleh putusan pengadilan yang terjadi karena alasan tertentu dan bersifat mendesak serta penting, misalnya terjadinya peralihan kepemilikan, aset maupun pailit sebagaimana ketentuan Pasal 165 dan juga Pasal 68, 154 huruf b.

Menurut Ilmu Kaidah Hukum Ketenagakerjaan, sumber hukum ketenagakerjaan meliputi Kaidah Otonom dan Kaidah Heteronom. ${ }^{2}$

\section{Kaidah Otonom}

Kaidah Hukum Otonom yaitu ketentuan hukum bidang ketenagakerjaan yang dibuat oleh para pihak, dimana para pihak tersebut terikat dalam hubungan kerja, baik itu hubungan antara pengusaha dengan pekerja/buruh dan hubungan antara pengusaha dengan serikat pekerja/serikat buruh. Bentuk-bentuk Kaidah Otonom Hukum Ketenagakerjaan adalah sebagai berikut:

i) Perjanjian Kerja

Merupakan perjanjian antara pekerja/buruh dengan pengusaha atau pemberi kerja yang memuat syarat-syarat kerja, hak, dan kewajiban para pihak.

ii) Peraturan Perusahaan

Merupakan peraturan tertulis yang dibuat oleh pengusaha dimana memuat syarat-syarat kerja dan tata tertib perusahaan. Peraturan perusahaan dalam prakteknya terdapat banyak istilah. Beberapa ada yang mengistilahkan dengan peraturan kerja perusahaan, peraturan majikan, reglemen perusahaan, peraturan karyawan, maupun peraturan kepegawaian. ${ }^{3}$

\footnotetext{
${ }^{2}$ Aloysius Uwiyono,[et.,al.], Asas-Asas Hukum Perburuhan, (Rajawali Pers 2014).[7].

${ }^{3}$ F.X. Djumialdji, Perjanjian Kerja, Edisi Revisi, (Sinar Grafika 2010).[59].
} 
iii) Perjanjian Kerja Bersama

Merupakan perjanjian yang tercatat pada isntansi ketenagakerjaan sebagai hasil perundingan antara serikat pekerja/serikat buruh atau beberapa serikat pekerja/serikat buruh dengan pengusaha atau beberapa pengusaha.

iv) Kebiasaan

Kebiasaan digunakan apabila tidak ada ketentuan hukum yang mengaturnya. Kebiasaan bersifat tidak tertulis dan berlaku layaknya hukum. Kebiasaan tersebut tumbuh dan berkembang luas di masyarakat sesuai dengan pesatnya perkembangan jaman. Perkembangan hukum perburuhan kadang kala tertinggal oleh pesatnya kemajuan masyarakat, sehingga ada masalah-masalah yang timbul dengan tidak ada ketentuan hukum yang mengaturnya, dengan demikian jalan keluarnya ialah memakai hukum kebiasaan.

\section{Kaidah Heteronom}

Kaidah Hukum Heteronom yaitu ketentuan Hukum di bidang Ketenagakerjaan yang dibuat oleh suatu pihak diluar pihak yang memiliki ikatan hubungan kerja. Pihak ketiga dalam hal ini adalah Pemerintah dan bersifat dominan. Bentuk-bentuk Kaidah Heteronom Hukum Ketenagakerjaan adalah sebagai berikut:

i) Perundang-undangan Ketenagakerjaan

Maksud peraturan perundang-undangan ketenagakerjaan adalah baik undang-undang, maupun peraturan-peraturan lain selain undang-undang (UU), peraturan pemerintah (PP) dan aturan-aturan teknis lainnya. Pada saat ini, undang-undang sebagai sumber hukum ketenagakerjaan formal yang utama adalah:

a. Undang-undang Nomor 21 Tahun 2000 tentang Serikat Pekerja/Serikat Buruh;

b. Undang-undang Nomor 13 Tahun 2003 tentang Ketenagakerjaan;

c. Undang-undang Nomor 2 Tahun 2004 tentang Penyelesaian Perselisihan Hubungan Industrial. 


\section{ii) Perjanjian Internasional / Traktat}

Kedudukan traktat atau treaty atau perjanjian internasional sebagai sumber hukum internasional tidak diragukan lagi. Pada umumnya perjanjian ini memuat aturan yang mengikat secara umum. Sebagaimana asas pacta sunt servanda, negara merupakan rechtpersoon dan terikat dengan perjanjian internasional. ${ }^{4}$

Kebijakan ketenagakerjaan wajib dilakukan oleh pemberi kerja/ pengusaha yang memperkerjakan seseorang dan kebijakan tersebut dapat diwujudkan dalam suatu bentuk aturan baku minimal yang berlaku dalam suatu perusahaan/instansi kerja. Tujuan diterapkannya aturan baku minimal tersebut agar selama dalam hubungan kerja, pekerja/buruh tidak mendapatkan perlakuan yang melanggar hak pekerja. ${ }^{5}$

Aturan baku minimal ini, dapat berupa aturan mengenai jam kerja, jam istirahat, perlindugan kesehatan dan keselamatan kerja, perlindungan dari praktik-praktik diskriminasi dunia kerja, atau kebijakan pengupahan yang tidak sesuai aturan minimal yang berlaku. Selain itu dijamin pula hak-hak pekerja/buruh dalam berorganisasi dan berunding bersama. Aturan baku minimal tersebut harus mengacu pada standar ketentuan internasional yang tercantum dalam berbagai konvensi Internasional Labour Organization (selanjutnya disebut ILO).

Mengenai posisi Kaidah Otonom dan Kaidah Heteronom, pada dasarnya tujuan dibuat Kaidah Heteronom adalah untuk memberikan aturan dasar yang wajib ditaati dan dilaksanakan seluruh pihak atas segala hal berkaitan dengan obyek yang diatur. Pada dasarnya aturan tersebut menjadi pedoman utama oleh pekerja dan pengusaha dalam pembuatan Kaidah Otonom. ${ }^{6}$ Artinya Kaidah Heteronom

\footnotetext{
${ }^{4}$ Abdul R. Budiono, Hukum Perburuhan, Cetakan pertama, (Indeks 2009).[19].

5 Adrian Sutedi, Hukum Perburuhan, Cet. 1, (Sinar Grafika 2009).[252].

6 Yogo Pamungkas, (Staf Pengajar Hukum Perburuhan FH Universitas Trisakti dan Sekretaris Pusat Studi Hukum Ketenagakerjaan FH Universitas Trisakti), 'Memposisikan Hukum Perburuhan Heteronom dan Hukum Perburuhan Otonom', <http://www.hukumonline.com/berita/baca/ hol22640/memposisikan-hukum-perburuhan-heteronom-dan-hukum-perburuhan-otonom>, diunduh 24 Desember 2017.
} 
menjadi standar minimal yang harus dipatuhi dalam membuat Kaidah Otonom. Dengan kedudukan Kaidah Otonom yang berada di bawah Kaidah Heteronom, dengan demikian maka Kaidah Otonom tidak boleh bertentangan dengan Kaidah Heteronom. Apabila bertentangan maka dianggap tidak berlaku dan yang berlaku adalah ketentuan yang dikemas dalam Kaidah Heteronom. Dengan demikian Kaidah Otonom dapat berlaku apabila kualitasnya lebih tinggi atau minimal sama dengan dengan kualitas Kaidah Heteronom. Demikian pula sebaliknya apabila kualitas Kaidah Otonom dibawah atau lebih rendah dari Kaidah Heteronom maka Kaidah Otonom Kaidah Otonom tersebut telah bertentangan dengan Kaidah Heteronom dan dianggap tidak berlaku.

PHK karena memasuki usia pensiun termasuk salah satu PHK demi hukum. Meskipun selain Undang-Undang No. 13 Tahun 2003 tentang Ketenagakerjaan terdapat peraturan perundang-undangan lainnya yang mengatur mengenai batas usia pensiun, karena profesi guru telah terdapat pengaturan khusus, yaitu, Undang-Undang Nomor 14 Tahun 2005 tentang Guru dan Dosen, dengan demikian berlakulah asas lex specialis derogat legi generali (norma hukum khusus mengesampingkan norma hukum umum). Sehingga pengaturan mengenai batas usia pensiun guru mengacu pada Undang-Undang Nomor 14 Tahun 2005 tentang Guru dan Dosen.

Sehingga berdasarkan sumber hukum ketenagakerjaan, penerapan batas usia pensiun pada Guru Swasta atau Guru Non Pemerintahan kurang dari usia 60 tahun yang kemudian diatur dalam Perjanjian Kerja, Peraturan Perusahan atau Peraturan Kerja Bersama, supaya memiliki keberlakuan harus diatur agar kualitasnya lebih baik/lebih tinggi atau minimal sama dengan dengan kualitas Undang-Undang Nomor 14 Tahun 2005 tentang Guru dan Dosen. Artinya ketentuan batas usia pensiun yang diatur dalam Perjanjian Kerja, Peraturan Perusahan atau Peraturan Kerja Bersama minimal harus pada batas usia 60 tahun atau lebih, dan tidak dapat kurang dari batas usia tersebut. 


\section{Perlindungan Hukum Bagi Guru Swasta yang Dilakukan Pemutusan} Hubungan Kerja Karena Batas Usia Pensiun Kurang Dari Ketentuan Undang-

\section{Undang Guru dan Dosen}

Secara teoritis dikenal ada tiga jenis perlindungan kerja, yaitu, sebagai berikut: ${ }^{7}$

a. Perlindungan sosial atau kesehatan kerja

Jenis perlindungan yang berkaitan dengan usaha kemasyarakatan, bagi pekerja/ buruh dimungkinkan untuk mengembangkan dan memperbaiki kehidupannya sebagaimana manusia pada umumnya. Perlindungan sosial disebut juga dengan kesehatan kerja. ketentuan-ketentuan perlindungan sosial dalam Undang-Undang Nomor 13 Tahun 2003 tentang Ketenagakerjaan Bab X Pasal 68 dan seterusnya.

b. Perlindungan teknis atau keselamatan kerja

Jenis perlindungan yang menjaga pekerja/buruh agar terhindar dari bahaya/ kecelakaan kerja yang ditimbulkan sebagai akibat mengoperasionalkan alatalat kerja atau bahan yang dikerjakan. Perlindungan secara umum diistilahkan dengan perlindungan keselamatan kerja. Undang-Undang Nomor 13 Tahun 2003 tentang Ketenagakerjaan tidak mengatur secara khusus mengenai keselamatan kerja dan sampai sekarang pengaturan keselamatan kerja diatur pada UndangUndang Nomor 1 Tahun 1970 tentang Keselamatan Kerja.

c. Perlindungan ekonomis atau jaminan sosial

Jenis perlindungan kepada pekerja/buruh untuk memberikan suatu penghasilan yang dapat digunakan untuk pemenuhan kebutuhan harian keluarga. Meliputi ketidakmampuan pekerja/buruh untuk bekerja karena suatu sebab diluar kehendaknya.

Sebelum membahas hak-hak Guru Swasta yang dilakukan pemutusan hubungan kerja, akan sedikit disinggung mengenai hak-hak guru secara umum yang diatur dalam Pasal 14 Undang-Undang Nomor 14 Tahun 2005 tentang Guru dan Dosen, yaitu:

\footnotetext{
${ }^{7}$ Universitas Borobudur Jakarta, 'Pengertian Tenaga Kerja, Undang-Undang dan Jenis Perlindungan', <https://www.facebook.com/notes/universitas-borobudur-jakarta/undang-undang-jaminan-dan-jenis-perlindungan-tenaga-kerja/546860785327961/>, diunduh 02 Januari 2018.
} 
a. Memperoleh penghasilan di atas kebutuhan hidup minimum dan jaminan kesejahteraan sosial;

b. Mendapatkan promosi dan penghargaan sesuai dengan tugas dan prestasi kerja;

c. Memperoleh perlindungan dalam melaksanakan tugas dan hak atas kekayaan intelektual;

d. .... dst.

Lebih lanjut, guru juga mendapat hak untuk terkait dengan perlindungan hak atas kekayaan intelektual dalam pelaksanaan tugasnya, ketentuan Pasal 39 ayat (1) dan ayat (4) Undang-Undang Nomor 14 Tahun 2005 tentang Guru dan Dosen mengatur bahwa perlindungan dalam melaksanakan tugas meliputi perlindungan hukum, perlindungan profesi, serta perlindungan keselamatan dan kesehatan kerja. Perlindungan profesi sebagaimana dimaksud mencakup perlindungan terhadap pemutusan hubungan kerja yang tidak sesuai dengan peraturan perundang-undangan. Dalam Pasal 31 peraturan tersebut mengatur bahwa: "Guru pada satuan pendidikan yang diselenggarakan oleh masyarakat yang diberhentikan dengan hormat tidak atas permintaan sendiri memperoleh kompensasi finansial sesuai dengan perjanjian kerja atau kesepakatan kerja bersama”. Dengan demikian maka, Undang-Undang Nomor 14 Tahun 2005 tentang Guru dan Dosen memberikan ketetentuan pada Guru Swasta yang dilakukan PHK dengan hormat tidak atas permintaan sendiri, termasuk salah satunya karena batas usia pensiun, berhak untuk memperoleh kompensasi finansial. Namun demikian, undang-undang tersebut tidak memberikan pengertian mengenai kompensasi finasial dan tidak mengatur besaran/nominal serta prosedur pemberian kompensasi finansial karena para pihak, dalam hal ini Guru Swasta dan/atau Satuan Pendidikan Swasta, dapat mengatur dalam perjanjian kerja atau kesepakatan kerja bersama.

Ketentuan mengenai hak-hak pekerja yang dilakukan PHK dalam Undangundang Nomor 13 Tahun 2003 tentang Ketenagakerjaan diatur pada Pasal 156-157. Dimana dalam Pasal 156 ayat (1) ditegaskan sebagai berikut: "Dalam hal terjadi pemutusan hubungan kerja, pengusaha diwajibkan membayar uang pesangon dan atau uang penghargaan masa kerja dan uang penggantian hak yang seharusnya dierima”. Hal yang perlu digaris bawahi mengenai pesangon ini yang harus 
dibedakan dari ganti rugi untuk tenggang waktu pernyataan pengakhiran, selain itu perlu dibedakan pula dari ganti rugi untuk pemberhentian yang tidak beralasan. Pertimbangan ini dan kenyataan bahwa pesangon itu biasanya adalah seimbang dengan lamanya aktivitas dan masa kerja dari pekerja bersangkutan serta kadang pula dibayarkan apabila pekerja meninggalkan perusahaan/instansi kerja atas permintaan sendiri. Sehingga pesangon dapat dimaknai sebagai kompensasi atas kesetiaan pekerja selama melakukan pekerjaan atau suatu pemberian upah tambahan yang pembayarannya ditangguhkan atau simpanan wajib ataupun bagian dari nilai perusahaan yang menjadi bertambah karena hasil dari usaha pekerja.

Berdasarkan seluruh uraian di atas, maka dapat disimpulkan suatu pemahaman terkait hak-hak Guru Swasta yang dilakukan pemutusan hubungan kerja sebagaimana berikut:

1. Menurut teori Hukum Ketenagakerjaan, Guru Swasta berhak memperoleh perlindungan kerja berupa perlindungan ekonomis atau jaminan sosial sebagai suatu bentuk yang dapat disamakan dengan santunan berupa uang sebagai ganti hilangnya sebagian penghasilan usia pensiun;

2. Menurut Undang-Undang Nomor 14 Tahun 2005 tentang Guru dan Dosen, Guru Swasta berhak memperoleh perlindungan profesi. Selain itu, Guru swasta juga dapat memperoleh suatu kompensasi dalam bentuk fiansial sebagaimana yang tertuang dalam perjanjian kerja atau kesepakatan kerja bersama.

Namun karena undang-undang tersebut tersebut tidak memberikan pengertian mengenai kompensasi finasial dan tidak mengatur besaran/nominal serta prosedur pemberian kompensasi finansial, maka berdasarkan teori sumber Hukum Ketenagakerjaan dapat mengacu kembali kepada Peraturan perudangundangan Ketenagakerjaan lainnya yang mengatur secara umum mengenai hakhak pekerja yang dilakukan PHK, yaitu, Undang-undang Nomor 13 Tahun 2003 tentang Ketenagakerjaan.

3. Menurut Undang-undang Nomor 13 Tahun 2003 tentang Ketenagakerjaan, Guru Swasta berhak memperoleh uang pesangon, uang penghargaan masa kerja, uang penggantian hak dan jaminan hari tua. Perhitungan uang pesangon, 
uang penghargaan masa kerja dan uang penggantian hak dapat diberikan sesuai dengan ketentuan yang berlaku berdasarkan masa kerja yang ditempuh.

Timbulnya perselisihan dalam ketenagakerjaan antara pengusaha dengan para pekerja/buruh umumnya karena sebab timbul perasaaan kurang puas. Menurut Pengusaha, kebijakan yang diberikan sudah baik dan dapat diterima oleh para pekerja/buruh tetapi pekerja/buruh memiliki pemahaman dan pertimbangan yang berbeda dengan pengusaha. Bagi pekerja yang merasa puas dapat meningkatkan hasil kinerja, namun tidak demikian halnya dengan pekerja yang tidak puas dapat menurunkan semangat kerja yang berakibat perselisihan. ${ }^{8}$ Di masa lalu penyelesaian perselisihan hubungan kerja diatur di dalam Undang-Undang Nomor 22 Tahun 1957 tentang Penyelesaian Perselisihan Perburuhan juncto Undang-Undang Nomor 12 Tahun 1964 tentang Pemutusan Hubungan Kerja di Perusahaan Swasta. Dua Undang-Undang ini dinyatakan tidak berlaku oleh Undang-Undang Nomor 2 Tahun 2004 tentang Penyelesaian Perselisihan Hubungan Industrial. ${ }^{9}$

Dalam undang-undang tersebut, yang dimaksud dengan perselisihan hubungan industrial adalah perbedaaan pendapat yang mengakibatkan pertentangan antara pengusaha dengan pekerja/buruh atau serikat pekerja/serikat buruh karena adanya perselisihan mengenai hak, perselisihan pemutusan hubungan kerja, serta perselisihan antarserikat pekerja/serikat buruh dalam satu perusahaan. Dengan demikian, perselisihan hubungan industrial meliputi hal-hal sebagai berikut:

a. Perselisihan mengenai hak;

b. Perselisihan mengenai kepentingan;

c. Perselisihan mengenai PHK;

d. Perselisihan mengenai serikat pekerja/serikat buruh dalam satu perusahaan.

Upaya penyelesaian perselisihan dalam hubungan industrial dapat ditempuh menggunakan jalur baik di luar Pengadilan Hubungan Industrial maupun melalui jalur Pengadilan Hubungan Industrial.

a. Penyelesaian Perselisihan Di Luar Jalur Pengadilan Hubungan Industrial

${ }^{8}$ Zaeni Asyhadie, 'Pemutusan Hubungan Kerja (PHK)', dalam Zainal Asikin,[et.,al.], DasarDasar Hukum Perburuhan, (Raja Grafindo Persada 2006).[201].

9 Abdul R. Budiono.Op.Cit.[77]. 
Para pihak yang berselisih wajib mengupayakan terlebih dahulu perundingan Bipartit dan apabila kesepakatan tercapai, hasil kesepakatan dituangkan dalam persetujuan bersama, namun apabila kesepakatan tida tercapai maka dapat ditempuh upaya lainnya melalui mediasi, konsiliasi, atau arbitrase. ${ }^{10}$

1. Upaya Penyelesaian dengan Bipartit

Tahap pertama untuk semua jenis perselisihan dalam hubungan industrial, termasuk juga perselisihan PHK, diselesaikan dengan perundingan bipartit atau perundingan dua pihak terlebih dahulu. Pihak yang berselisih dalam hubungan kerja adalah pengusaha dengan pekerja/buruh. Tujuan diadakannya upaya bipartit agar permasalahan dapat diselesaikan secara kekeluargaan, dan diharapkan para pihak tidak merasa keberatan dan dapat saling menerima hasil kesepakatan. Penyelesaian hasil proses bipartit bersifat mengikat para pihak. Sebelum para pihak yang bersengketa menempuh upaya penyelesaian lainnya, para pihak waib menempuh terlebih dahulu upaya bipartit ini.

2. Upaya Penyelesaian dengan Konsiliasi

Penyelesaian perselisihan hubungan industrial melalui proses ini ditempuh dengan cara musyawarah. Jenis penyelesaian ini wajib ditengahi oleh seorang atau lebih konsiliator yang tidak memiliki kecenderungan berpihak pada salah satu pihak. Perselisihan yang dapat ditempuh dengan cara ini meliputi:

a. Masalah Perselisihan kepentingan;

b. Masalah Perselisihan PHK;

c. Masalah Perselisihan antar serikat pekerja/serikat buruh di satu perusahaan.

3. Penyelesaian Melalui Arbitrase

Arbitrase hubungan industrial merupakan penyelesaian perselisihan antar serikat pekerja/serikat buruh yang mengalami benturan kepentingan. Jenis penyelesaian ini dilakukan di luar jalur Pengadilan Hubungan Industrial menggunakan suatu kesepakatan dalam bentuk tertulis dari para pihak yang mengalami perselisihan dan kemudian hasil kesepakatan tersebut diserahkan

${ }^{10}$ Adrian Sutedi.Op.Cit.[108]. 
kepada arbiter. Perselisihan yang dapat ditempuh dengan cara ini meliputi:

a. Masalah Perselisihan kepentingan;

b. Masalah Perselisihan antar serikat pekerja/serikat buruh di satu perusahaan.

4. Penyelesaian Melalui Mediasi

Penyelesaian perselisihan hubungan industiral melalui proses ini ditempuh dengan cara musyawarah dan wajib ditengahi oleh seorang atau lebih mediator yang tidak memiliki kecenderungan berpihak pada salah satu pihak. Para pihak berselisih yang tidak memilih cara penyelesaian melalui konsiliasi ataupun arbitrase yang ditawarkan oleh instansi ketenagakerjaan, maka wajib menempuh jalur mediasi. Perselisihan yang dapat ditempuh dengan cara ini meliputi:

a. Masalah Perselisihan hak;

b. Masalah Perselisihan kepentingan;

c. Masalah Perselisihan PHK;

d. Masalah Perselisihan antar serikat pekerja/serikat buruh di satu perusahaan.

b. Penyelesaian Perselisihan Melalui Jalur Pengadilan Hubungan Industrial

Pengertian Pengadilan Hubungan Industrial menurut Pasal 1 angka 17 Undang-Undang Nomor 2 Tahun 2004 tentang Penyelesaian Perselisihan Hubungan Industrial adalah: "Pengadilan khusus yang dibentuk di lingkungan Pengadilan Negeri yang berwenang memeriksa, mengadili dan memberi putusan terhadap perselisihan hubungan industrial.

Kewenangan absolut Pengadilan Hubungan Industrial untuk memeriksa dan memutus menurut ketentuan Pasal 56 yaitu:

1. Masalah mengenai hak di tingkat pertama;

2. Masalah mengenai perselisihan kepentingan di tingkat pertama dan tingakt terakhir;

3. Masalah PHK di tingkat pertama;

4. Masalah perselisihan antar serikat pekerja/serikat buruh di tingkat pertama dan terakhir.

Terkait Guru Swasta yang dilakukan PHK dapat dilakukan upaya hukum sebagai berikut:

1. Penyelesaian perselisihan yang terlebih dahulu harus ditempuh adalah menggunakan jalur di luar pengadilan hubungan industrial. Karena perselisihan 
menyangkut PHK, maka cara yang dapat ditempuh antara lain penyelesaian melalui bipartit. Upaya selain bipartit, yaitu konsiliasi dan mediasi, dapat ditempuh apabila tidak tercapai kesepakatan dalam upaya bipartit. Karena jalur arbitrase tidak dimungkinkan dalam penyelesaian perselisihan hubungan kerja.

2. Penyelesaian perselisihan di luar jalur pengadilan hubungan industrial yang mengalami kegagalan, maka upaya melalui jalur pengadilan hubungan industrial dapat ditempuh dengan cara pengajuan gugatan oleh salah satu pihak yang berselisih kepada Pengadilan Hubungan Industrial pada Pengadilan Negeri yang disertai dengan risalah penyelesaian mediasi atau risalah penyelesaian konsiliasi. Daerah hukum Pengadilan Negeri meliputi tempat dimana Guru Swasta tersebut bekerja.

\section{Kesimpulan}

a. Guru Swasta yang mendapat penerapan pensiun pada batas usia 60 tahun, yang ketentuannya diatur dalam suatu Perjanjian Kerja, Peraturan Perusahaan atau Peraturan Kerja Bersama, supaya memiliki keberlakuan harus diatur agar kualitasnya lebih baik/lebih tinggi atau minimal sama dengan kualitas UndangUndang Nomor 14 Tahun 2005 Tentang Guru dan Dosen. Artinya ketentuan batas usia pensiun yang diatur dalam Perjanjian Kerja, Peraturan Perusahan atau Peraturan Kerja Bersama minimal harus pada batas usia 60 tahun atau lebih, dan tidak dapat kurang dari batas usia tersebut.

b. Mengenai Guru Swasta yang dilakukan PHK oleh Penyelenggara Pendidikan Swasta terkait batas usia pensiun kurang dari 60 tahun sebagaimana ketentuan Undang-Undang Guru dan Dosen, dapat dilakukan upaya hukum dengan terlebih dahulu harus melakukan penyelesaian perselisihan terlebih dahulu di luar jalur pengadilan hubungan industrial. Karena perselisihan menyangkut masalah PHK, maka upaya yang dapat ditempuh antara lain penyelesaian melalui bipartit. Apabila upaya bipartit telah ditempuh dan mengalami kegagalan, maka upaya mediasi atau konsiliasi dapat ditempuh karena penyelesaian perselisihan hubungan industrial tidak dimungkinkan upaya arbitrase. Apabila penyelesaian 
perselisihan di luar jalur pengadilan hubungan industrial mengalami kegagalan, maka upaya melalui jalur pengadilan hubungan industrial dapat ditempuh dengan cara pengajuan gugatan oleh salah satu pihak yang berselisih kepada Pengadilan Hubungan Industrial pada Pengadilan Negeri yang disertai dengan risalah penyelesaian mediasi atau risalah penyelesaian konsiliasi. Daerah hukum Pengadilan Negeri meliputi tempat dimana Guru Swasta tersebut bekerja.

\section{Daftar Bacaan}

\section{Buku}

Asyhadie, Zaeni, "Pemutusan Hubungan Kerja (PHK)", dalam Zainal Asikin et.al., Dasar-Dasar Hukum Perburuhan, Raja Grafindo Persada, Jakarta, 2006.

Budiono, Abdul Rachmad, Hukum Perburuhan (Indeks 2009).

Bruggink, J. J. H. (alih bahasa: Arif Sidharta, S.H.), Refleksi Tentang Hukum (Cet. 1, Citra Aditya Bakti 1996).

Collins, Hugh, K.D Ewing, and Aileen McColgan, Labour Law-Text and Materials (Hart Publishing 2005).

Djumialdji, F.X., Perjanjian Kerja (Edisi Revisi, Sinar Grafika 2010).

Garner, Bryan A., ed., Black's Law Dictionary (Tenth Edition, Thomson Reuters 2014).

Hasibuan, Malayu S.P., Manajemen Sumber Daya Manusia (Cet. 12, Bumi Aksara 2012).

Husni, Lalu, Pengantar Hukum Ketenagakerjaan Indonesia (Raja Grafindo Persada 2003).

Kamus Besar Bahasa Indonesia (Balai Pustaka 1990).

Marzuki, Peter Mahmud, Penelitian Hukum (Prenada Media Group 2005).

Panggabean, Mutiara S., Manajemen Sumber Daya Manusia (Cet. 2, Ghalia Indah 2004).

Price, Rohan, Employment Law in Principle (Lawbook, Co., Pyrmont 2007). 
Ramli, Lanny, Hukum Ketenagakerjaan (Airlangga University Press 2008).

Rusli, Hardijan, Hukum Ketenagakerjaan 2003 (Ghalia Indonesia 2004).

Siagian, Sondang P., Manajemen Sumber Daya Manusia, (Bumi Aksara 2012).

Soepomo, Imam, Pengantar Hukum Perburuhan (Djambatan 1982).

Subekti, R. dan R. Tjitrosudibio, Kitab Undang-undang Hukum Perdata (Burgerlijk Wetboek) (Cet. 25, Pradnya Paramita 1992).

Sutedi, Adrian, Hukum Perburuhan (Cet. 1, Sinar Grafika 2009).

Uwiyono, Aloysius et al., Asas-Asas Hukum Perburuhan (Rajawali Pers 2014).

Wahab, H. Agusfian, "Sumber-sumber Hukum Perburuhan", dalam Zainal Asikin et.al., Dasar-Dasar Hukum Perburuhan (Raja Grafindo Persada 2006).

\section{Perundang-undangan}

Kitab Undang-undang Hukum Perdata (Burgerlijk Wetboek), Cet. 25, (terjemahan Prof. R. Subekti dan R. Tjitrosudibio), Jakarta: Balai Pustaka, 1992.

Undang-Undang Republik Indonesia Nomor 3 Tahun 1992 tentang Jaminan Sosial Tenaga Kerja (Lembaran Negara Nomor 14 Tahun 1992, Tambahan Lembaran Negara Nomor 3468).

Undang-Undang Republik Indonesia Nomor 11 Tahun 1992 tentang Dana Pensiun (Lembaran Negara Nomor 37 Tahun 1992, Tambahan Lembaran Negara Nomor 3477).

Undang-Undang Republik Indonesia Nomor 43 Tahun 1999 tentang Perubahan atas Undang-Undang Nomor 8 Tahun 1974 tentang Pokok-Pokok Kepegawaian (Lembaran Negara Nomor 169 Tahun 1999, Tambahan Lembaran Negara Nomor 3890).

Undang-undang Republik Indonesia Nomor 13 Tahun 2003 tentang Ketenagakerjaan (Lembaran Negara Nomor 39 Tahun 2003, Tambahan Lembaran Negara Nomor 4279).

Undang-Undang Republik Indonesia Nomor 2 Tahun 2004 tentang Penyelesaian Perselisihan Hubungan Industrial (Lembaran Negara Nomor 6 Tahun 2004, Tambahan Lembaran Negara Nomor 4356).

Undang-Undang Republik Indonesia Nomor 14 Tahun 2005 tentang Guru dan Dosen (Lembaran Negara Nomor 157 Tahun 2005, Tambahan Lembaran 
Negara Nomor 4586).

Undang-Undang Republik Indonesia Nomor 24 Tahun 2011 tentang Badan Penyelenggara Jaminan Sosial (Lembaran Negara Nomor 116 Tahun 2011, Tambahan Lembaran Negara Nomor 5256).

Undang-Undang Republik Indonesia Nomor 5 Tahun 2014 tentang Aparatur Sipil Negara (Lembaran Negara Nomor 6 Tahun 2014, Tambahan Lembaran Negara Nomor 5494).

Peraturan Pemerintah Republik Indonesia Nomor 21 Tahun 2014 tentang Pemberhentian Pegawai Negeri Sipil yang Mencapai Batas Usia Pensiun Bagi Pejabat Fungsional (Lembaran Negara Nomor 58 Tahun 2014).

Peraturan Pemerintah Republik Indonesia Nomor 45 Tahun 2015 tentang Penyelenggaraan Program Jaminan Pensiun (Lembaran Negara Nomor 155 Tahun 2015, Tambahan Lembaran Negara Nomor 5715).

Peraturan Pemerintah Republik Indonesia Nomor 11 Tahun 2017 tentang Manajemen Pegawai Negeri Sipil (Lembaran Negara Nomor 63 Tahun 2017, Tambahan Lembaran Negara Nomor 6037).

Keputusan Menteri Tenaga Kerja Republik Indonesia Nomor 48/MEN/IV/2004 tentang Tata Cara Pembuatan dan Pengesahan Peraturan Perusahaan serta Pembuatan dan Pendaftaran Perjanjian Kerja Bersama.

Keputusan Menteri Tenaga Kerja Republik Indonesia Nomor 100/MEN/VI/2004 tentang Ketentuan Pelaksanaan Perjanjian Kerja Waktu Tertentu.

\section{Laman}

Serikat Pekerja PT. Tanjungenim Lestari Pulp And Paper, 'Usia Pensiun Jadi Pertanyaan', <http://sppt-tel.blogspot.co.id/2015/12/usia-pensiun-jadipertanyaan.html $>$, diunduh 25 Juli 2017.

Sugi Arto, 'Pengertian, Dasar, Ruang Lingkup dan Sumber Hukum Tenaga Kerja', $<$ http://artonang.blogspot.co.id/2014/12/pengertian-dasar-ruang-lingkupdan.html $>$, diunduh 24 Desember 2017.

Yogo Pamungkas (StafPengajar Hukum Perburuhan FHUniversitas Trisakti dan Sekretaris Pusat Studi Hukum Ketenagakerjaan FH Universitas Trisakti), 'Memposisikan Hukum Perburuhan Heteronom dan Hukum Perburuhan Otonom', <http://www. hukumonline.com/berita/baca/hol22640/memposisikan-hukum-perburuhanheteronom-dan-hukum-perburuhan-otonom>, diunduh 24 Desember 2017.

HOW TO CITE: Hafin Auni Qashrina, 'Batas Usia Pensiun Guru Swasta Ditinjau Berdasarkan Undang-Undang Nomor 13 Tahun 2003 Tentang Ketenagakerjaan’ (2018) Vol. 1 No. 3 Media Iuris. 